Erratum

\title{
Erratum: Jasper, David. Seeking Christian Theology in Modern Chinese Fiction: An Exercise for Sino-Christian Theology. Religions 10 (2019): 422
}

\author{
David Jasper(D) \\ Department of Theology and Religious Studies, The University of Glasgow, Glasgow G12 8QQ, UK; \\ davidjasper124@gmail.com
}

Received: 6 August 2019; Accepted: 6 August 2019; Published: 8 August 2019

The author wants to make the following corrections to the paper (Jasper 2019):

(Chuang 2010) Chuang, Tzu. 2010. The Inner Chapters. Translated by Solala Towler. London: Watkins Publishing.

(Hua 2003) Hua, Yu. 2003. To Live. Translated by Michael Berry. New York: Anchor Books.

(Hua 2004) Hua, Yu. 2004. Chronicle of a Blood Merchant. Translated by Andrew F. Jones. New York: Anchor Books.

(Huilin 2014) Huilin, Yang. 2014. China, Christianity, and the Question of Culture. Waco: Baylor University Press.

(Huilin 2010) Huilin, Yang. 2010. The Value of Theology in the Humanities: Possible Approaches to Sino-Christian Theology. In Sino-Christian Theology: A Theological Qua Cultural Movement in Contemporary China. Edited by Pan-chui Lai and Jason Lam. Frankfurt: Peter Lang, pp. 101-22.

(Keyi 2015) Keyi, Sheng. 2015. Northern Girls. Translated by Shelly Bryant. Beijing: Penguin Books China, p. 319.

(Lianke 2007) Lianke, Yan. 2007. Serve the People! Translated by Julia Lovell. London: Constable. (Youzhuang 2016) Youzhuang, Geng. 2016. Between East and West: Word and Image. Waco: Baylor University Press.

should be

(Chuang Tzu 2010) Chuang Tzu. 2010. The Inner Chapters. Translated by Solala Towler. London: Watkins Publishing.

(Yu 2003) Yu, Hua. 2003. To Live. Translated by Michael Berry. New York: Anchor Books.

(Yu 2004) Yu, Hua. 2004. Chronicle of a Blood Merchant. Translated by Andrew F. Jones. New York: Anchor Books.

(Yang 2014) Yang, Huilin. 2014. China, Christianity, and the Question of Culture. Waco: Baylor University Press.

(Yang 2010) Yang, Huilin. 2010. The Value of Theology in the Humanities: Possible Approaches to Sino-Christian Theology. In Sino-Christian Theology: A Theological Qua Cultural Movement in Contemporary China. Edited by Pan-chui Lai and Jason Lam. Frankfurt: Peter Lang, pp. 101-22.

(Sheng 2015) Sheng, Keyi. 2015. Northern Girls. Translated by Shelly Bryant. Beijing: Penguin Books China, p. 319.

(Yan 2007) Yan, Lianke. 2007. Serve the People! Translated by Julia Lovell. London: Constable.

(Geng 2016) Geng, Youzhuang. 2016. Between East and West: Word and Image. Waco: Baylor University Press.

The manuscript will be updated and the original will remain online on the article webpage.

We would like to apologize for any inconvenience caused. 
Conflicts of Interest: The author declares no conflict of interest.

\section{Reference}

Jasper, David. 2019. Seeking Christian Theology in Modern Chinese Fiction: An Exercise for Sino-Christian Theology. Religions 10: 422. 